\title{
Alternative energy supply system to a rural village in Ethiopia
}

\author{
Gudina Terefe Tucho $^{1 *}$ and Sanderine Nonhebel ${ }^{2}$
}

\begin{abstract}
Background: Most households in rural developing countries do not have access to modern energy supply. Household level biogas energy was considered as an option but failed due to lack of sufficient resources for its installation and operation. A community energy system can be an option, but most studies focused on off-grid electricity. This energy system cannot be a realistic option particularly for cooking demand. An efficient and suitable system matching local resources and demand expectation needs to be developed which this study focuses on assessing. Biogas and solar energy technologies are viable to establish such kind of a system since they can be converted to different forms of energy. Therefore, this study aims to determine efficient biogas and solar energy production and utilization options for small scale village energy application in rural Ethiopia.

Methods: The efficiencies of the production and utilization options are determined based on the system configurations involving resource, conversion, and utilization combination models. We used local resources, data, and relevant literature information for the system analysis.

Results: The analysis shows that most energy is needed in the form of heat for cooking and a smaller part in the form of electricity (about 10\%). The community waste stream converted to biogas will be enough for cooking, but not enough biogas is left to produce enough electricity. Co-digesting altogether provides biogas that can meet only about $75 \%$ of the electricity demand. Concentrated solar cookers can be an alternative for cooking in areas where installation of biogas is not possible. About 2- $\mathrm{m}^{2}$ size solar concentrator is sufficient to meet each household's cooking energy demand. The lighting and appliance energy demand can be met with photovoltaic (PV) energy produced with reasonably sized panels. However, the use of electrical energy for cooking produced with PV cannot be an economic option with the available technologies.
\end{abstract}

Conclusions: The community energy system involving anaerobic co-digestion (biogas) and/or solar energy technologies is viable to meet the demand when efficient production and conversion is made based on specific local resource supply and demand.

\section{Background}

Modern energy is vital to any economic development and societal well-being. Societies in rural developing countries are deprived of modern energy access at least for basic cooking, lighting, and powering of low voltage appliances. Presently, these services are met with the traditional use of biomass energy, kerosene, and dry cell batteries $[1,2]$. The traditional use of biomass energy is inefficient and unclean and involves huge negative socioeconomic and environmental consequences. In

\footnotetext{
* Correspondence: guditerefe@gmail.com

'Department of Environmental Health Sciences and Technology, Jimma

University, Jimma, Ethiopia

Full list of author information is available at the end of the article
}

principle, biomass (converted to biogas) and solar energy sources are viable to meet the demand since they can be converted into different energy forms. Biogas can be directly combusted to provide heat for cooking and can be converted into electricity for different services. Similarly, solar energy can be converted into electricity within a photovoltaic cell (PVC) and concentrated to provide heat for cooking (concentrated solar cooker (CSC)) and electricity with a concentrated solar power (CSP) system.

Since recent decades, family size biogas digesters and PV as solar home systems (SHSs) have been considered in most energy policies and promoted to solve rural energy problems. China and India are among developing 
countries who have taken the leading role by installing millions of family size biogas digesters in rural areas [3]. Most Sub-Saharan Africa countries followed the Chinese and Indian example and adopted biogas technologies for their rural energy needs [4-6]. However, in practice, application of biogas is often limited by poor resource availability, and that of solar by the high costs of the PVCs [6-8]. As a consequence, most households either cannot afford the costs of installation or do not have sufficient feedstock and water to run the digesters $[6,9]$. A recent study made in Sub-Saharan Africa clearly identified the prevailing bottleneck on the broadening of small scale biogas digesters in the region [10]. Most of them installed through certain financial support also are not functioning due to shortage of feedstock and water and technical problems [7]. Shortage of feedstock is attributed to the traditional use of only cow dung limited by the number of cows held at households. Only few households with a sufficient number of cows can produce enough biogas to meet their demand [11, 12]. In addition, adoption and installation of household level biogas digesters are limited by the long payback period associated with the technology [13, 14]. Therefore, a household level renewable energy system cannot be a realistic option for the majority of poor households in rural developing countries.

Shortage of feedstock can be averted by use of any available organic waste. Up till now, human excreta has not been getting favorable attention as a potential biogas feedstock due to low level of awareness $[15,16]$. However, human excreta are important bio-wastes which could have huge potential similar to that of livestock manure. Furthermore, use of human excreta for biogas production provides huge sanitation and fertilizer benefits. In western countries, sewage sludge provides much contribution to biogas production as a co-digestion feedstock $[17,18]$.Crop residues contain a high carbon to nitrogen $(\mathrm{C} / \mathrm{N})$ ratio enabling high biogas yields. Co-digesting these waste streams allows efficient use of available resources for better biogas yields of good quality energy. Anaerobic co-digestion can be applicable in households but is easier at the village level due to the benefits of lower labor requirements for its operation and availability of different biowastes for sharing.

A village energy system is not a new concept; several decentralized off-grid energy systems involving different energy sources have been studied for rural communities which have no access to conventional grids [19-21].These studies focused on developing hybridized energy sources for electricity generation. Electrical energy is superior in quality to provide heat for cooking and power for appliances. However, it may not be suitable to provide an adequate solution to rural energy issues due to varying local energy demands and technological choices. Households need different forms of energy for different services; thus, a combination of sources providing heat and electricity is needed to meet the demand. Given the overall system demands of reliability and sufficiency of resources, these designs should be compared to arrive at an optimal solution. An optimal solution for local energy demand partly relies on the technologies used to convert to useful energy capable of performing certain tasks. Different technologies provide varying types of useful energy due to varying conversion efficiencies [8, 22-24]. Nevertheless, most of these conversion technologies cannot fit to rural demand due to factors attributed to local socioeconomic, cultural, and technical conditions. To the best of our knowledge, comprehensive studies combining local demand, resources, and technological efficiencies and suitability to provide an alternative option to rural developing country's energy issues is not available.

In this paper, we evaluate other options to provide energy to rural villages in Africa, as the literature shows many individual households do not have enough resources to run the digesters. Therefore, first we take the village perspective, and next we look for other sources as feedstock for biogas production. With a village perspective, households are supposed to share their resources irrespective of their holdings. The village energy system is considered based on the reported success stories of institutional and community biogas digesters installed in Sub-Saharan Africa [10]. This approach allows both rich and poor households to share their resources and helps to have access to technical and financial support $[6,7]$.With a family biogas system, households depend on cow dung limited by the number of available live animals. On a community level, differences between households are avoided and resources could be averaged to a production system able to produce reliable, efficient, and sufficient volumes of biogas. Secondly, most of the studies on rural community energy focus on an off-grid electrical energy system. However, electrical energy alone cannot provide solution to a rural community's energy demand. Thirdly, most studies focus either on few energy sources or energy services. In this paper, we evaluate the most relevant energy supply system configurations involving different production, conversion, and utilization combinations providing heat for cooking and electricity for lighting and appliances. The aim of this study is therefore to determine efficient biogas and solar energy production and utilization options for small scale village energy application in rural Ethiopia. The results of the study are vital in assisting energy policy makers and planners to consider appropriate technology that can meet the energy needs of a rural village. 


\section{Methods}

The energy system description consists of at least three parts that should be considered and be related to each other: the supply of energy sources, the conversion of energy sources into useful energy carriers (like heat and electricity), and the demand for these energy carriers (or energy services). In this paper, we determine the resources available at the village level and evaluate whether they are sufficient to produce enough energy to meet local demands. We used available local data sources and relevant literature for the analysis. The amounts of resources available to meet these demands are limited due to limited supply and competing purposes; thus, efficient production and utilization is needed. Therefore, alternative energy system configurations composed of biogas and solar energy providing different energy forms are developed to determine efficient production and utilization options.

Biogas can be produced from any type of organic waste of agricultural, industrial, and residential origin. For proper functioning of the digester, a constant supply of biomass of a certain quality is essential. We consider bio-wastes from agricultural and residential origins. Agricultural wastes include crop residues and cow dung whereas residential bio-wastes are household cleaning and human excreta. At present, crop residues are mostly used for feeding and cow dung for fertilizer and human excreta are disposed of in rural areas. These waste streams contain varying nutritional compositions that can support varying co-digestion options; thus, they were considered in this study. Up till now, cow dung serves as the main feedstock in rural areas around the world; thus, a biogas yield from digestion of cow dung alone is considered as a reference for the co-digestions.

Different technologies are available to convert biogas into different forms of energy. It can be converted to heat energy through direct combustion in biogas burners (stoves) or converted to electricity in combustion engines. Direct use of biogas is popular and technically mature in developing countries since it involves only a digester, stoves, and few fixtures. Conversion of biogas into electricity is also becoming popular in both developing and developed countries. Direct conversion both into heat and into electrical energy is considered in this study.

The schematic diagram involving different biogas production and utilization options is shown in Fig. 1. The figure shows different waste stream processing and conversion options for different energy services. Therefore, the efficiency of the system is determined based on the amount of biogas produced per amount of bio-wastes digested (co/mono) and converted to meet the demands. Thus, the choice between different systems depends on the availability of resources and the suitability of the technology for local energy demands.

The net useful energy value of $1 \mathrm{t}$ of co-digested biowaste is therefore estimated by multiplying its biogas yield $\left(\mathrm{m}^{3} / \mathrm{t}\right)$ by its lower energy value $\left(\mathrm{MJ} / \mathrm{m}^{3}\right)$ and conversion efficiency of the devices ( ).The final useful energy required for the demand is presented in GJ $\left(10^{9} \mathrm{~J}\right)$.

In areas where application of biogas is limited, solar energy can be an option to meet the cooking and electrical energy demands. The incoming solar radiation contains radiation of varying wavelengths that can be converted into different forms of energy. The amount of radiation absorbed and converted into energy carriers depends on the type of materials used for collection and conversion.

There are also different solar energy technologies to concentrate solar radiation at high temperature for electricity generation (CSP) or to combine heat and electricity as hybrid thermal photovoltaic (PVT), but they are not feasible to apply in rural areas. In this study, we analyze solar PVC and CSC based on their current application in different regions of the world in particular in developing countries. In PV, direct solar energy is converted into electricity by semi-conducting materials while CSC uses concentrated heat for direct use. Both direct conversion into electricity with PV and concentration into heat for cooking are considered in this study for alternative analysis.

The amount of useful energy obtained per square meter area of solar collector depends on the technical efficiencies of the devices and local solar irradiation.

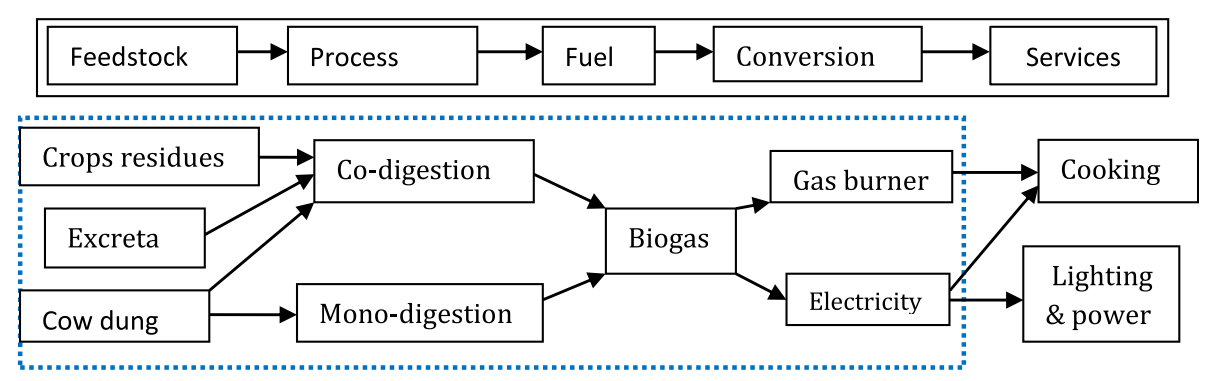

Fig. 1 Biogas energy production process and conversion for direct use for cooking and electricity for appliances 
This is calculated by multiplying the annual average solar irradiation per square meter (I) by the conversion efficiency of the system ( ) [1]. This in turn determines the area required to meet the energy demands of the village. Therefore, the area required to meet the demand with each technology is calculated by dividing the demand to the useful energy obtained per square meter solar collector. The schematic diagram involving different solar energy conversion technologies is shown in Fig. 2. This system also focuses on system configuration aimed at producing heat for cooking and electricity for appliances.

The resources required to meet the demand rely on the system efficiency expressed with the amount of useful energy obtained for end-use services (i.e., cooking food, lighting homes, etc.). In this study, five alternative energy system configurations involving biogas and solar energy technologies are analyzed. These are:

1. A dual use of biogas for both cooking and appliances. In this configuration, biogas is supposed to provide electricity for appliances and direct heat energy for cooking. This system can be considered a cooking/electricity hybrid due to involvement of two separate technologies (stoves and engines) producing heat and electricity sharing the same biogas digester (biogas storage).

2. The second alternative biogas system configuration is conversion of biogas to electricity for both cooking and appliance demand.

3. In areas where biogas resources and technical competencies are insufficient, a hybrid configuration involving biogas for cooking and solar electricity for appliances can be used. This configuration is seemingly independent since biogas is used only for cooking and solar energy for the appliances.

Nevertheless, both sources are used in combination to provide energy services for the village as a whole.

4. In areas where application of biogas is limited, solar energy can be developed with two alternative options as a hybrid and standalone electricity system. When developed as a hybrid, CSC provides the cooking services while PV electricity is used for lighting and appliances. Alternatively, solar energy can be converted into electrical energy in PVC and used for cooking, lighting, and appliance energy demand in one unit. Unlike biogas, solar energy is independent of locally produced resources, so the decision to choose between the systems relies on the size of the solar collector required for the demand and other technical issues.

The above configurations are analyzed based on the specific assumptions presented in the "Availability of energy resources," "Energy technologies," and "Energy demand profile" sections of the paper.

\section{Availability of energy resources Bio-waste}

Bio-wastes can be produced from industrial processing, residential activities, and agricultural areas. Agricultural bio-wastes are produced when cereal crops are collected from farm lands. These types of bio-wastes are produced as straw, husk, and stalk and are referred to primary or field residues. Agricultural bio-wastes also include dung from livestock animals. These waste streams are relatively abundant in rural areas although the amounts available at households depend on the sizes of their land and livestock resources. Data on land resources and corresponding cereal crop yields and cattle population holdings are taken from Ethiopian CSA databases [25]. The quantities of bio-wastes produced from household resources and their availabilities are determined in a previous study [11] based on the average residue to product ratio (RPR) of cereal crops $[26,27]$ and dry dung per animal $[3,28,29]$. Accordingly, households annually on average produce about $3 \mathrm{t}\left(1 \mathrm{t}=10^{3} \mathrm{~kg}\right)$ of residues and $3 \mathrm{t}$ of dung from their land and cattle resources respectively. Both bio-wastes are an integral part of the rural agricultural system where residues are additionally used for soil mulching, feeding, and animal bedding. Specific data for each use is not available for the country, but up to $85 \%$ of residues can be removed in areas where mixed farming is used [30]. Availability of dung is also limited

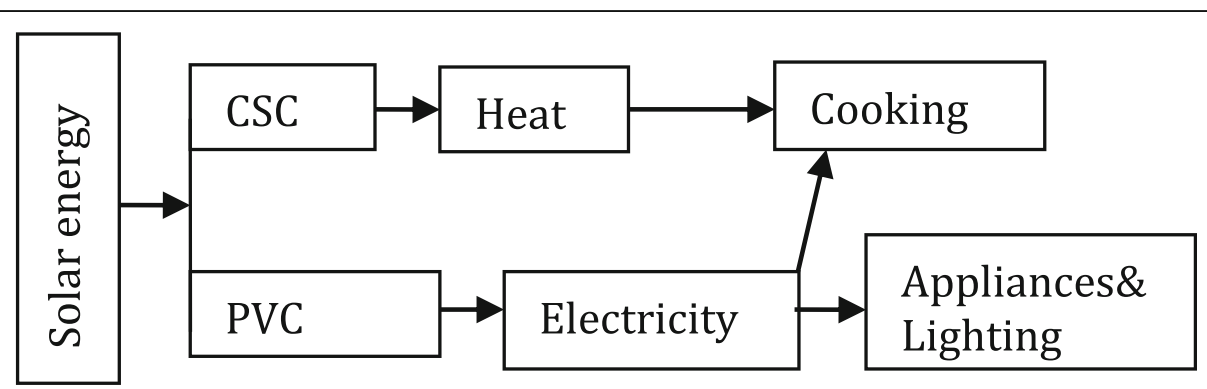

Fig. 2 Solar energy conversion into heat and electricity for cooking and appliances 
by feeding practices and the need for fertilizers. As a consequence, only about $30 \%$ of produced residues and $40 \%$ of produced dung are assumed to be available for energy based on [11].With these, we estimated about $22 \mathrm{t}$ of residues and $30 \mathrm{t}$ of dry dung per year from the average land and cattle resources of the village respectively (Table 1).

Data on the quantity and composition of rural household wastes are not available for Ethiopia to include in this study. Human excreta are sufficiently available in rural areas with essential nutritional compositions. They contain high amounts of organic matter capable of being converted to biogas and also provide huge sanitation and fertilizer benefits [16, 31]. Unlike other bio-wastes, human excreta contain both solid and liquid components produced as feces and urine. The amount of excreta a person produces varies from place to place due to living conditions, varying nutritional composition, and type and amount of foods consumed [32]. Hence, it varies from 80 to $140 \mathrm{~g} /$ person/day in developed countries and from 250 to $520 \mathrm{~g} /$ person/day in developing countries [33, 34]. The amount of urine a person daily excretes depends on the quantity of consumed water, physical activities, and prevailing weather; thus, it varies from 1.0 to $1.6 \mathrm{~L}[33,35]$. Each year, one person on average produces about $50 \mathrm{~kg}$ of dry feces and $500 \mathrm{~L}$ of urine $[3,31]$. The total solid contents of urine vary from 4 to $9 \%$ [33].This study considered an average dry solid content of $5 \%$ for its energy potential. All the produced feces and urine may not be available for collection due to movement of people during the day; we assume a reasonable availability of $80 \%$. Based on this, we estimated an annual yield of about $6 \mathrm{t}$ of dry feces and $60 \mathrm{~m}^{3}$ ( $3 \mathrm{t}$ of dry contents) of urine, totaling about $9 \mathrm{t}$ for the typical village studied here. The potential quantities of bio-wastes produced from the village resources and their available portion for biogas production are presented in Table 1.

\section{Solar energy}

The country's solar radiation data is taken from NASA surface meteorology and renewable energy databases and from literature $[1,36]$. The amount of solar energy obtained from a certain area depends on the intensity of local solar irradiation. The daily solar irradiation of the country varies from 18 to $25 \mathrm{MJ} / \mathrm{m}^{2}\left(5-7 \mathrm{kWh} / \mathrm{m}^{2} /\right.$ day) [1].On average, about $22 \mathrm{MJ} / \mathrm{m}^{2}\left(6 \mathrm{kWh} / \mathrm{m}^{2} /\right.$ day $)$ can be obtained at an effective eight sun-hours, equivalent to about $750 \mathrm{~W}$. The variation might be associated with variation in cloud cover during the rainy season and altitudinal patterns, since there is no clear distinction between winter and summer for the country. In a temperate climate, the intensity and availability of solar energy depends on the seasons of the year due to variation in the length of day and night. This is not the case in a tropical climate where an overhead sun is present throughout the year with an almost equal length of day and night. In the absence of cloud and rain, no variation can be observed on the amount of radiation received daily. Such weather dependent variation may not affect the annual solar energy budgets (i.e., availability and intensity). Annually, an average incident solar irradiation intensity of about $8 \mathrm{GJ} / \mathrm{m}^{2}$ or $2190 \mathrm{kWh} / \mathrm{m}^{2}$ can be received. This is the gross solar energy budget of the country considered in this study.

\section{Energy technologies \\ Biogas production and conversion}

Different sizes of anaerobic digesters ranging from family size to agricultural sizes were installed in SubSaharan Africa [37]. In Ethiopia, more than 90 institutional biogas plants with a size of $12-350 \mathrm{~m}^{3}$ have been installed, of which more than $50 \%$ of them are functioning $[38,39]$. In this study, a centralized community biogas system with the capacity to accommodate the energy demand of the village is considered. Such kinds of digesters are suitable to manage different varieties of bio-wastes as a co-digestion feedstock.

Conversion of bio-wastes to biogas consists of four phases with different species of bacteria operating in different specific anoxic environmental conditions [40]. The level of performance at each phase and ultimate biogas yield relies on feedstock composition and process operation involving complex biochemical reactions. Imbalance of the carbon to nitrogen ratio $(\mathrm{C} / \mathrm{N})$ of biowastes would have a significant impact on the reactor environment and subsequent biogas yields. A high or low $\mathrm{C} / \mathrm{N}$ ratio is not desirable for the microbial digestion processes. For instance, feedstock with high nitrogen

Table 1 Annual bio-waste production and its available potential for a village energy system

\begin{tabular}{llllll}
\hline Feedstock & Resources of the village & Annual yield & Produced bio-wastes $(\mathrm{t})$ & Availability coefficients & Available bio-waste(t) \\
\hline Cows dung & 100 cows & $0.7 \mathrm{t} /$ cow & 73 & 0.4 & 30 \\
Human feces & 150 persons & $0.05 \mathrm{t} /$ capita & 7.5 & 0.8 & 6 \\
Human urine & 150 persons & $0.5 \mathrm{~m}^{3} /$ capita & $75 \mathrm{~m}^{3}$ & 0.8 & $60 \mathrm{~m}^{3}(3 \mathrm{t})$ \\
Crop residues & 23 ha & $3 \mathrm{t} / \mathrm{ha}$ & 69 & 0.3 & 22 \\
Total & & & & 61
\end{tabular}

$1 \mathrm{~m}^{3}$ of urine $=1 \mathrm{t}$ corresponding to $50 \mathrm{~kg}$ of dry biomass (5\%) 
content (i.e., low $\mathrm{C} / \mathrm{N}$ ratio) facilitates production of ammonia toxic to methane producing microbes. Too high a carbon content (high $\mathrm{C} / \mathrm{N}$ ratio) is also not suitable due to the enhancement of hydrolysis processes and drops in the $\mathrm{pH}$ of the system. The optimum $\mathrm{C} / \mathrm{N}$ ratio for effective performance of $\mathrm{AD}$ (anaerobic digestion) and biogas yield is 20-30:1 [41]. The optimum ratios can be achieved by adjusting the feedstock carbon and nitrogen contents. Cow dung contains a low $\mathrm{C} / \mathrm{N}$ ratio while crop residues contain a high ratio [41, 42]. Therefore, addition of plant materials with high carbon content to cow dung inhibits production of ammonia and a drop in $\mathrm{pH}$. Human feces and urine have varying organic matter and nutritional compositions [31, 32, 43]. Addition of human feces and urine either to cow dung or residues or to both would have an enhancing effect on the system performance and good quality biogas yield.

The biogas yields from co-digestions of different biowastes are reviewed and presented in Table 2. The data shows varying biogas yields ranging from 200 to $500 \mathrm{~m}^{3} / \mathrm{t}$ of co-digested bio-wastes. The yield variation in codigestion can be attributed to different environmental and operational conditions [44]. As shown in the data, digesting cow dung alone provides a relatively low biogas yield compared to co-digesting with crop residues. The advantage of co-digestion is not only increasing the yield of biogas but also provides the possibility to use any bio-waste. Co-digestion of the three waste streams (crops residues, cow dung, and human excreta) undoubtedly helps to increase the yield of biogas and its methane contents. In this study, an average biogas yield of $350 \mathrm{~m}^{3} / \mathrm{t}$ of co-digested dry bio-waste is considered based on the biogas yield data presented in Table 2. The amount of useful energy gotten out of the resulting biogas depends on the technologies involved in conversion.

Theoretically, biogas is a mixture of $60-75 \% \mathrm{CH}_{4}$ and $25-40 \% \mathrm{CO}_{2}$ with a calorific value of about $20-25 \mathrm{MJ} /$ $\mathrm{m}^{3}[27,45]$.The processes of digestion and feedstock composition determine the proportion of methane and other gases. Its energy value and conversion efficiency depends on the methane content. This is crucial when the gas is converted into different forms of energy like heat and electricity. Several technologies are available to convert biogas into electricity and heat at varying conversion efficiencies.

Up till now, the mature technology to convert biogas directly into heat at household scale is a biogas burner (stove). A biogas stove is technically mature to adapt and modify its design to make it suitable to cook local foods [22]. Biogas containing low methane provides low thermal efficiency due to increased carbon dioxide content and reduction in rate of combustion. Thus, its thermal efficiency varies from about 50 to $68 \%$ with a biogas consumption rate of $0.220-0.450 \mathrm{~m}^{3}$ per hour $[22,46,47]$. One of the ways to improve the methane content of biogas is through adjustment of the feedstock composition with co-digestion. In this study, high methane contents are expected due to consideration of co-digestion. Taking this into account, an average thermal energy efficiency of about $60 \%$ is assumed for the typical biogas burner studied here.

Use of biogas for electricity generation may follow a similar pattern of conversion where design modification and quality of biogas can play a major role. Conversion

Table 2 An overview of biogas yield data from co-digestions available in literature

\begin{tabular}{|c|c|c|c|c|}
\hline Feedstock & Feeding ratio & Biogas yield & Unit & Ref. \\
\hline Cow dung (CD) & $100: 0$ & 0.280 & $\mathrm{~m}^{3} / \mathrm{kg}$ of TS & {$[3,27,44]$} \\
\hline Crop residues (CR) & 100:0 & 0.400 & $\mathrm{~m}^{3} / \mathrm{kg}$ of TS & {$[45,46]$} \\
\hline CD alone & 100:0 & 0.233 & $\mathrm{~m}^{3} \mathrm{CH}_{4}$ per kg VS & [47] \\
\hline$C D$ and $C R$ & $60: 40$ & 0.268 & $\mathrm{~m}^{3} \mathrm{CH}_{4}$ per kg VS & \\
\hline CD alone & 100:0 & 0.210 & $\mathrm{~m}^{3} / \mathrm{kg}$ of $\mathrm{VS}$ & [48] \\
\hline$C D, C R$, and energy crops (EC) & $50: 25: 25$ & 0.540 & $\mathrm{~m}^{3} / \mathrm{kg}$ of $\mathrm{VS}$ & \\
\hline CD and corn stover (CS) & $25: 75$ & 0.356 & $\mathrm{~m}^{3} / \mathrm{kg}$ of $\mathrm{VS}$ & {$[37,39]$} \\
\hline CD and corn stover (CS) & $50: 50$ & 0.325 & $\mathrm{~m}^{3} / \mathrm{kg}$ of $\mathrm{VS}$ & \\
\hline $\mathrm{CD}$ alone & 100:0 & 0.230 & $\mathrm{~m}^{3} / \mathrm{kg}$ of $\mathrm{VS}$ & [41] \\
\hline CD and crop silage (CSi) & $90: 10$ & 0.465 & $\mathrm{~m}^{3} / \mathrm{kg}$ of $\mathrm{VS}$ & \\
\hline CD and crop silage (CSi) & $80: 20$ & 0.477 & $\mathrm{~m}^{3} / \mathrm{kg}$ of $\mathrm{VS}$ & \\
\hline Human excreta alone & $100: 0$ & $0.35-0.5$ & $\mathrm{~m}^{3} / \mathrm{kg}$ of TS & {$[3,43]$} \\
\hline Food waste and human feces & N/A & 0.410 & $\mathrm{~m}^{3} \mathrm{CH}_{4} / \mathrm{kg}$ of $\mathrm{VS}$ & [43] \\
\hline$C D$, urine, and water & 50:0:50 & 37 & $L / \mathrm{kg}$ of fresh dung & [42] \\
\hline$C D$, urine, and water & $50: 35: 15$ & 48 & $\mathrm{~L} / \mathrm{kg}$ of fresh dung & \\
\hline
\end{tabular}

TS total solid, VS volatile solid 
of biogas into electricity in an internal combustion engine requires engine modification either to a dual engine where a mixture of diesel and biogas is used or to a spark ignition engine to use with pure biogas [22]. The methane content of the biogas is critical for use in an internal combustion engine; thus, a concentration of $\mathrm{CO}_{2}$ above $40 \%$ is not desirable for the engine performance [48]. Most studies made on engines running on biogas fuel reported an electrical energy conversion efficiency of about $30-40 \%[49,50]$.In this study, a conversion efficiency of about $30 \%$ is considered taking into account the complex combustion characteristics of biogas. The quantity of useful energy derived from a unit cubic meter of biogas is therefore determined by its energetic value and the technical efficiencies of the devices.

\section{Solar energy conversion technologies}

The direct incoming solar radiation contains radiation of varying wavelengths. In PV cells, only solar radiation with appropriate wavelengths is converted to electricity. The light absorbing materials used for PVC production vary from amorphous silicon to thin film materials $[8,51]$. Amorphous silicon can achieve about 5-8\% electricity conversion efficiency, while mono- and polycrystalline silicon technologies have an efficiency of around 14-19\%. More than $19 \%$ electricity conversion efficiency can be achieved with thin film materials. PV made of amorphous silicon is technically mature and less costly but relatively inefficient, and thin film materials are more efficient but expensive. In this study, an average electrical energy conversion efficiency of about $15 \%$ is assumed, presumably an efficiency of PV cells made up of crystalline silicon materials.

Solar energy can be concentrated for household cooking energy with a concentrated solar cooking technology. Concentration of solar energy does not require expensive light absorbing materials like that of PV cells; at small scale, local materials like packaging can be used [52]. CSCs are available with different designs and sizes for outdoor and indoor cooking [53]. It enables an integration of heat storage media for a suitable cooking schedule. Heat storage with steam using parabolic concentrators are being utilized successfully for community level residential evening meal cooking in India [53]. Most of the available CSCs provide low thermal efficiencies requiring a cooking time of 2-4 h [54]. Most CSCs have thermal efficiencies varying from 20 to $50 \%$ due to varying design of the cookers and concentrators [55]. However, a lot of improvements have been made and are in progress on the thermal efficiency of CSCs [56-58]. Higher thermal efficiencies (50-60\%) are already reported with parabolic solar cookers (PSCs) [59]. A simple CSC with a simple design is easily applicable and familiar in developing countries compared to PSCs requiring relatively more advanced radiation focusing materials. A simple type of CSCs with about $30 \%$ thermal efficiency is considered in this study taking into account their application and level of technical maturity in rural areas. The amount of useful energy obtained per square meter area of solar collector depends on the technical efficiencies of the devices and local solar irradiation (Table 3).

\section{Energy demand profile}

The village energy demand is composed of cooking, lighting, and powering appliances. Cooking can be met with primary heat energy from burning of biogas and concentration of solar energy. Lighting and appliances exclusively need electrical energy. The analyses are made as cooking (heat) and electricity (appliances) demand, since the shares of energy for lighting and appliances are too small to be analyzed separately.

More than $99 \%$ of the households living in rural village rely on traditional use of biomass energy for cooking and about $60 \%$ use kerosene wick lamps for lighting [1]. The household energy demand profile used in this study is made based on the demand estimation available in the relevant literature [60]. The assumption made in electrical energy unit in the literature is converted to energy unit for the sake of comparison with the energy from biomass. The assumptions are based on daily use of four lamps of $11 \mathrm{~W}$ for lighting, $70 \mathrm{~W}$ for $\mathrm{TV}$, and $5 \mathrm{~W}$ each for radio receiver and mobile charger serving for about $5 \mathrm{~h}$. This provides an equivalent annual village energy consumption of about 7 GJ of useful energy for lighting and 13 GJ for appliances (20 GJ of useful energy for both). The data also includes a 3-kW-rated power stove for baking local food (Injera) for 45 min every 2 days. An additional 2-kW-power-rated electric double stove for daily cooking for other foods with an estimated cooking time of $2 \mathrm{~h}$ per day is included as well. The annual energy required for both types of cooking is estimated to be equivalent to about $163 \mathrm{GJ}$ of useful energy. This assumption is in line with the annual cooking demand estimation made in a previous study, which is 5-7 GJ of useful energy per household [11]. Overall, the village annually requires about $163 \mathrm{GJ}$ of useful energy for cooking and $20 \mathrm{GJ}$ of useful energy for lighting and appliances. The advantage of using useful energy for the demand estimations is that it does not vary with the technologies used for the services. It is the amount of energy required to perform certain tasks (i.e.,

Table 3 Annually available useful solar energy potential with different conversion technologies

\begin{tabular}{lll}
\hline Gross solar energy $\mathrm{GJ} / \mathrm{m}^{2}$ & \multicolumn{3}{l}{ Useful energy per technologies in $\mathrm{GJ} / \mathrm{m}^{2}$} \\
\cline { 2 - 3 } & PV & CSC \\
\hline 7.9 & 1.2 & 2.4 \\
\hline
\end{tabular}


delivered to food for cooking, empower devices, etc.). The largest (about 90\%) part of the energy is required for cooking.

\section{System analysis}

The typical village considered here requires annually about $163 \mathrm{GJ}$ of useful energy for cooking and $20 \mathrm{GJ}$ for lighting and appliances. The energy needed to meet this demand comes from available biogas and solar energy resources. So, first we determine how much energy can be produced from the available resources. The energy from available biomass resources is estimated based on their biogas energy potentials as single and co-digestion feedstock. The resulting biogas is subjected to different forms of energy conversion as heat and electricity. Similar estimation is made for solar energy conversion. These energy potentials are analyzed with different system configurations to determine efficient production and utilization options matching to local resources and demand. Availability of biogas depends on locally produced resources, so whether this is sufficient is determined by the difference between supply and demand presented as a gap. The gap can be positive or negative due to varying combinations of resources in the co-digestion and technical efficiencies of the technologies considered. Unlike biogas, the availability of solar energy does not depend on local resources; thus, it is evaluated based on the size of solar collectors. The decision regarding the technologies of choice relies on the possibility to match local resources with the demands and its suitability to meet local expectations. Local expectations in turn refer to the ability of the technology to meet local needs without involving complex production and conversion processes. Thus, the results for each biogas configuration are presented in gigajoules of energy and that of solar energy is with the size of solar collectors meeting the demand in square meters.

\section{Results}

With the data derived above, the amounts of resources required for the demand with different biogas and solar energy configurations are calculated. The results with the biogas system configurations are presented in Figs. 3 and 4a. Accordingly, we estimated about 339 GJ of energy for the system composed of direct use of biogas for cooking with biogas stoves and conversion to electricity for appliances (Fig. 3a). The cooking demand in a biogas stove requires about $272 \mathrm{GJ}$ of gross biogas energy to produce the $163 \mathrm{GJ}$ of useful energy required for cooking (Fig. 4a). Production of the 20-GJ equivalent electrical energy needed for the appliance demand requires 67 GJ of gross biogas energy. Conversion to electricity for both cooking and appliance demand requires about 610 GJ of gross biogas energy (Fig. 3b).

The result presented in Table 3 shows the amount of energy obtained with different anaerobic digestion options. Digesting the available cow dung alone provides about 172 GJ of biogas energy. More energy can be obtained when co-digestions are applied. About 389 and $285 \mathrm{GJ}$ are obtained when cow dung is co-digested with crop residues and human excreta respectively. Codigestion of human excreta and crop residues provides about $243 \mathrm{GJ}$, whereas co-digesting them together with cow dung yields about $458 \mathrm{GJ}$. It is the maximum amount of energy the resources available in the village can provide. Converting all in biogas stoves on average provides about 275 GJ of useful energy and 137 GJ when converted to electricity (Table 4).

The results on resource demands of different biogas system configurations are presented in Figs 3 and 4a. The data shows the potential supply and demand and their differences as a gap. The supply-demand gaps are shown with broken lines. The available resources are sufficient when the difference between supply and demand is positive. This is determined by the proportion of resources in

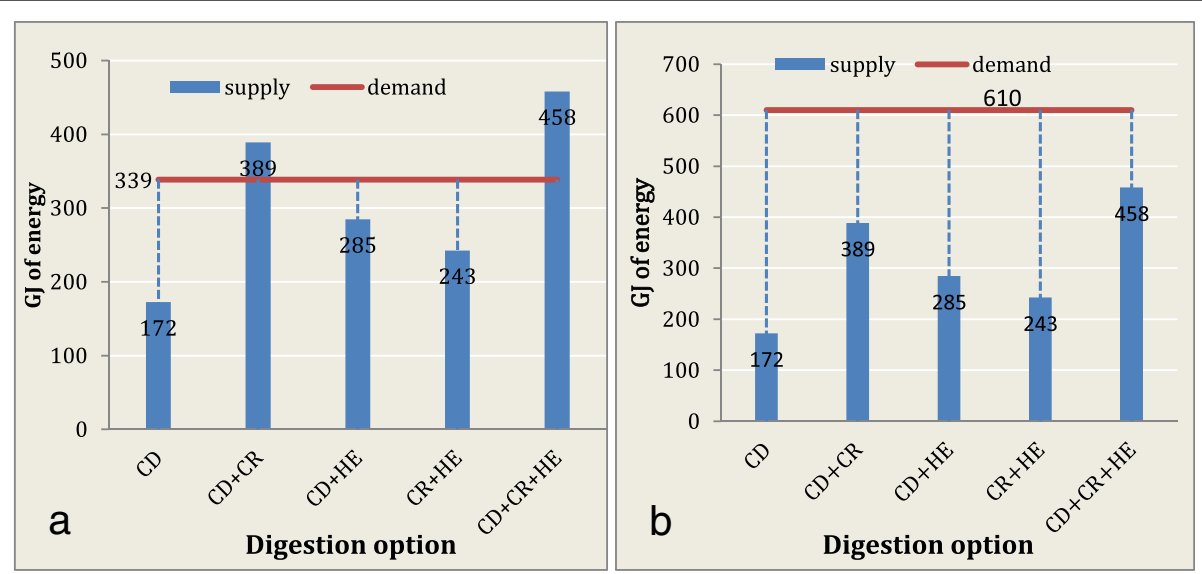

Fig. 3 a A hybrid of biogas for direct cooking and its electricity for appliances. b Biogas electricity for both cooking and appliances 


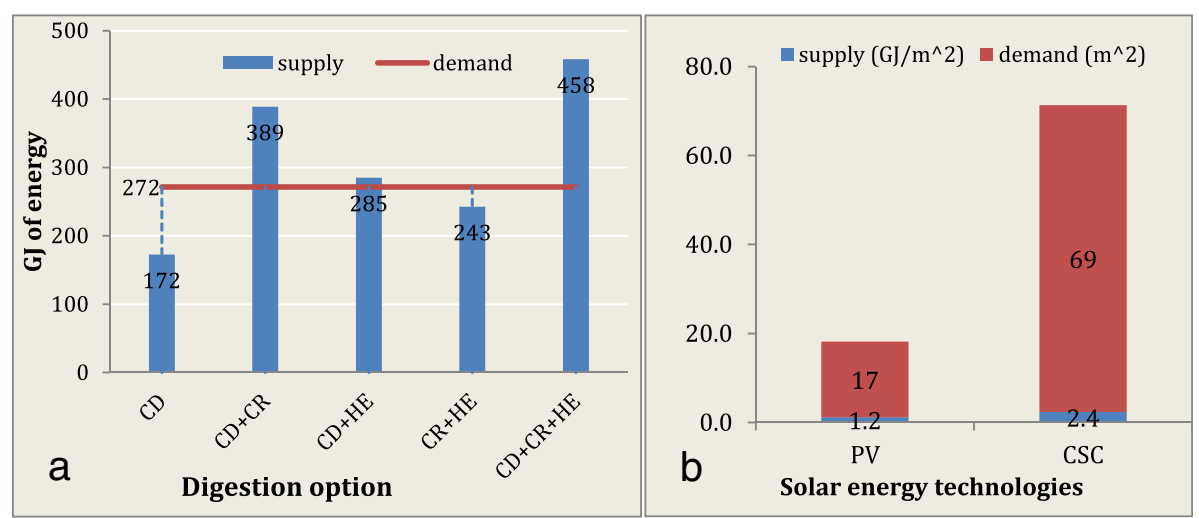

Fig. 4 A hybrid of $\mathbf{a}$ biogas for cooking and $\mathbf{b}$ solar PV for appliances and CSC for cooking

the co-digestion, yields of biogas, and methods of conversion. In the co-digestion involving cow dung with either residues or excreta, the resulting energy is sufficient for the demand when the gas is directly used for cooking (Figs. 3a and 4a). Nevertheless, a co-digestion involving crop residues and human excreta is not enough for the demand due to their low proportion in the co-digestion. None of the resources with any of the co-digestion options are sufficient to meet the demand when the gas is converted to electricity and used for both cooking and appliances. This system requires about $610 \mathrm{GJ}$ of gross biogas energy, but the available resources provide only $458 \mathrm{GJ}$ of energy. Meeting the demand with this configuration requires an extra $152 \mathrm{GJ}$ of energy on top of the amount the village resources can supply (Fig. $3 \mathrm{~b}$ ). The available resources are sufficient for both cooking and appliances when its gas is directly used for cooking and its electricity is for appliances. However, this may involve certain competition for gases. In that case, an electricity from PVC can be used alternatively for appliances leaving the biogas for cooking (Fig. 4b).
The results with exclusive solar energy configurations are presented in Fig. 5. This configuration involves the hybrid of heat and electricity and only electricity. The hybrid configuration includes the use of CSC for cooking and PV electricity for appliances. The size of solar collectors required to meet the demand depends on the local irradiation and device conversion efficiencies. On average, the country's direct solar irradiation provides an annual solar energy potential of about $8 \mathrm{GJ} / \mathrm{m}^{2}$. Taking into account the device conversion efficiency, CSC can convert about $2.4 \mathrm{GJ} / \mathrm{m}^{2}$ to useful energy for cooking (Table 3). With this estimate, the cooking energy demand of the village requires about $70-\mathrm{m}^{2}$ solar concentrator (about $2.5 \mathrm{~m}^{2}$ per household). One square meter of PV provides about $1.2 \mathrm{GJ}$; with this assumption, the appliance electricity demand requires about $17 \mathrm{~m}^{2}$ of PV. However, if the cooking energy demand is included, this PV size will be increase to about $155 \mathrm{~m}^{2}$ to meet both the $163 \mathrm{GJ}$ of useful energy needed for cooking and 20 GJ of useful energy for appliances. This is equivalent to an average size of $6.2 \mathrm{~m}^{2}$ of PV per household.

Table 4 Annual biogas energy production potential from the village biomass energy resources

\begin{tabular}{|c|c|c|c|c|c|c|}
\hline \multirow{2}{*}{$\begin{array}{l}\text { Biogas energy } \\
\text { sources }\end{array}$} & \multirow{2}{*}{$\begin{array}{l}\text { Dry matter } \\
\text { (t) }\end{array}$} & \multirow{2}{*}{$\begin{array}{l}\text { Availability } \\
(\%)\end{array}$} & \multirow{2}{*}{$\begin{array}{l}\text { Available potential } \\
\text { (t) }\end{array}$} & \multirow{2}{*}{$\begin{array}{l}\text { energy potential } \\
\text { (GJ/year) }\end{array}$} & \multicolumn{2}{|c|}{ Useful energy potential (GJ/year) } \\
\hline & & & & & Burner & Electricity \\
\hline Cow dung & 70 & 0.4 & 28 & 172 & 103 & 52 \\
\hline Crop residues & 75 & 0.3 & 23 & 198 & 119 & 59 \\
\hline Human feces & 7.5 & 0.8 & 6 & 46 & 28 & 14 \\
\hline Human urine & $3.8^{\mathrm{a}}$ & 0.8 & 3 & 23 & 14 & 7 \\
\hline$C D+C R$ & 145 & & 51 & 389 & 233 & 117 \\
\hline $\mathrm{CD}+\mathrm{HE}$ & 81 & & 37 & 285 & 171 & 85 \\
\hline $\mathrm{CR}+\mathrm{HE}$ & 86 & & 32 & 243 & 146 & 73 \\
\hline $\mathrm{CD}+\mathrm{CR}+\mathrm{HE}$ & 156 & & 60 & 458 & 275 & 137 \\
\hline
\end{tabular}

${ }^{\mathrm{a}}$ Total dry matter content of the annually produced urine 


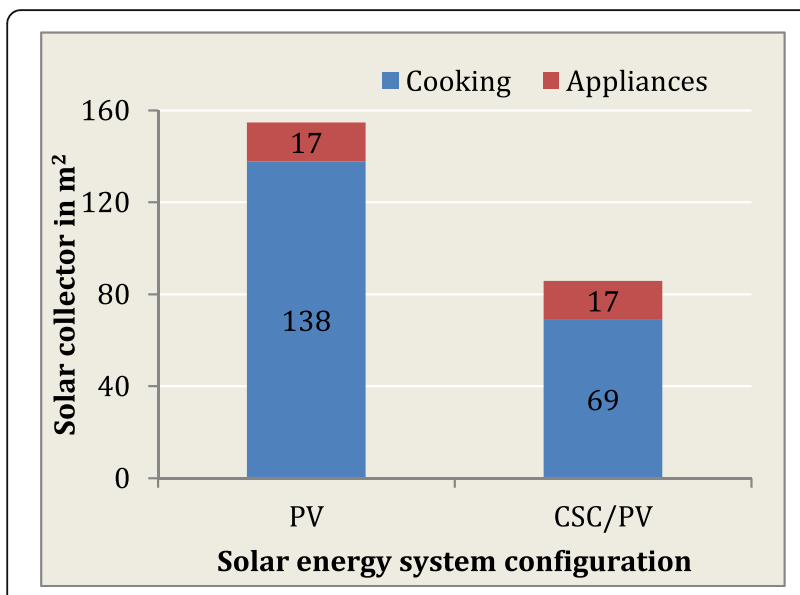

Fig. 5 Solar energy technology configurations for cooking and electricity

\section{Discussion}

\section{Consideration of co-digestion and a communal energy} system

We evaluated the availability and suitability of biogas and solar energy for a village energy application with different system configurations involving various production and utilization options. As stated in the paper, biogas production needs locally produced resources determined by the size of available resources, competing purposes, and condition of collection. Increasing the amount available for energy is less likely possible due to involvement of these extra factors. However, co-digestion provides the possibility of making local resources sufficient for the demands when the right proportions are considered. The proportion of feedstock depends on the available land, cows, and human population as well as its availability characteristics. It can be noted that none of the available bio-wastes are sufficient to meet the energy demands of the village as a single feedstock. However, their varying nutritional composition provides an opportunity for co-digestion. This helps to use the available resources efficiently.

The sufficiency of the resources for the demand relies on the efficiency of anaerobic digestion process and resulting increase in biogas yields. The efficiency of the digestion process depends on the right combination of the proportion of the bio-wastes and their nutritional composition in the co-digestion. In extreme situations, a system break and halt can occur when the process is dominated with either nitrogenous or carbonaceous biowastes. Excess of either of these nutrients will lead to the formation of acid or lower the $\mathrm{pH}$ of the system leading to hindrances of the processes of digestion and its biogas yield. Therefore, it is important to take into account the nutritional composition of the waste streams in particular their $\mathrm{C} / \mathrm{N}$ ratios when a system is designed for co-digestion. Available literature showed that co-digestion of different waste streams provides varying biogas yields from a minimum of $200 \mathrm{~m}^{3} / \mathrm{t}$ to over $500 \mathrm{~m}^{3} / \mathrm{t}$, although average values were considered in this study (Table 2). Accordingly, when the minimum values are taken into account, the resulting biogas is not sufficient to meet the cooking energy demand as shown in Fig. 4a. At least the yields of biogas should remain similar (no change to the yield) to the yields of digesting dung alone (reference feedstock) to meet the demand (Fig. 6). In summary, the resource sufficiency in this study partly relies on the proportion of waste streams and partly on the increasing biogas yields.

Feedstock adjustments are easier to apply at the village level than at a household level. Collection of crop residues and preparation for $\mathrm{AD}$ is labor intensive at the household level. Adjustment of the feed proportion with other waste streams also consumes a lot of time. One of the main limitations on sustainability of biogas technology is the labor cost incurred in resource collection and feeding [61]. All these activities can be easier to handle at the community level with few permanent laborers.

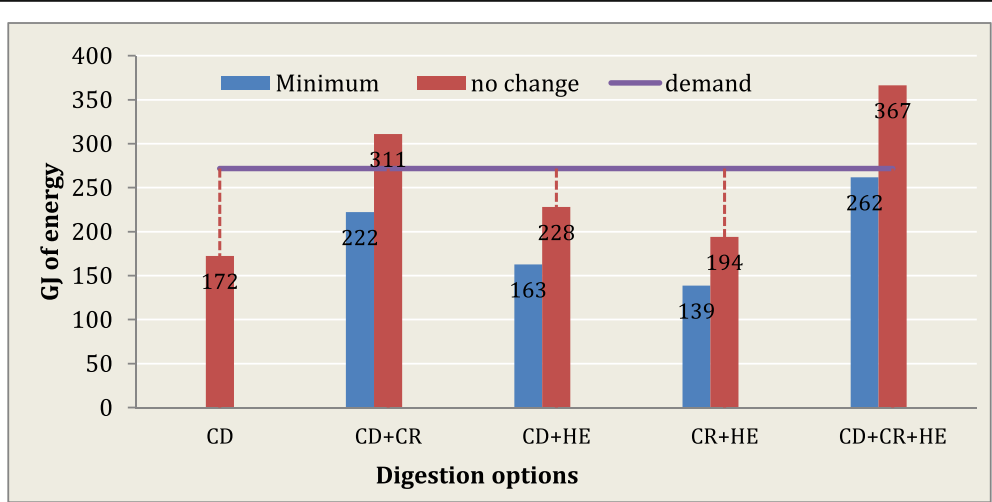

Fig. 6 Availability of biogas for cooking when varying biogas yields with different co-digestion options are considered. Minimum stands for the lowest biogas yield available in literature, and no change refers to the biogas yield of the reference feedstock (i.e., dung) 
This helps to avoid fragmented efforts of resource use, installation, and operation of the system in a household and saves much labor and costs specially for women [62]. Use of a community level biogas digester is a better option and advantageous than those that are family scale in many ways [10]. In general, the advantages of codigestion for resource use optimization and sufficiency for the demand is more realized when a communal energy system is considered.

\section{Benefits and challenges of considering human excreta as co-feedstock}

Human excreta give a substantial addition to the local energy resource potential. Its composition also helps optimization of the digestion process. Together with cow dung, it is continuously produced during the year. It is a non-resource competitive feedstock freely and abundantly available in rural areas [33-35]. Rural people mostly consume fibrous foods presumably containing high energy values of indigestible contents [33]. About $90 \%$ of the nitrogen contents of excreta come from urine and feces which contribute highly volatile organic matter [32, 33, 35]. As a single feedstock, the dry matter portions of both feces and urine contribute to about $25 \%$ of the cooking demands (Table 4). It is sufficient to meet the cooking energy demand of the village together with dung (Fig. 3a). Together with cow dung, it can save the quantity of residues removed for energy. Use of human excreta in co-digestion is beyond serving as feedstock; it helps to reduce the water requirement of the digesters.

To consider excreta for co-digestion, issues related to latrines in rural areas and the risk of pathogenic contamination need to be resolved. Most latrines in rural areas are made up of earthen materials (pit latrine) without linings. Such kind of latrines cannot hold water or is not suitable to connect to digesters. However, these problems can be solved with certain digester design modifications or with modified low cost latrines like EcoSan [32, 35]. EcoSan latrines allow separate collection of feces and urine without environmental contamination. Otherwise, the potential risk of contamination with enteric pathogenic organisms is high likely when the excreta are applied manually. In addition, in the processes of digestion, microbial load reduction can be achieved, but it is not sufficient to make it risk free [63].When digesters run in ambient temperature, most pathogenic microorganisms may remain active due to the favorable digestion environment. This may entail huge consequences if the slurry is used for fertilizer or released untreated. However, human pathogenic microorganisms cannot withstand high temperatures above $50{ }^{\circ} \mathrm{C}$, which can be achieved with the simple process of composting [34]. Human excreta are a non-resource competitive feedstock with huge contribution to rural sanitation, biogas yield, and crop yields if appropriately used.

\section{Consideration of biogas energy conversion technologies and its implication}

In the "Consideration of co-digestion and a communal energy system" and "Benefits and challenges of considering human excreta as co-feedstock" sections, we discussed the contribution of considering co-digestion and communal energy system in increasing the resource availability for the demand. Nevertheless, conversion technologies are equally (more) important in providing a sufficient and secure supply. The notion here is how to determine an appropriate technology that can achieve the greatest efficiency. Several efficient technologies are available, but they may not be realistic options to meet specific demands. So, the nature and quantity of a specific demand in relation to the available energy system and facilities are crucial. The largest share (about 90\%) of the household energy demand in the study area goes to cooking services. Cooking food needs thermal energy from the combustion of fuel or from a secondary source of energy (i.e., electricity). Combustion of fuel generates heat energy directly used for cooking without further processing. Without involving complex combustion processes, biogas stoves can provide high thermal efficiencies for cooking when their air-to-fuel ratios are properly adjusted $[22,64]$. This is shown with the results of a biogas configuration involving biogas stoves where available resources are sufficient to meet the demand even with excess gas available for other purposes (Fig. 3a).

Moreover, biogas stoves can easily be made compatible to cook local foods with minor stove modifications [65]. Compatibility to local cooking needs would increase the suitability and acceptability of the technology to meet local expectations. However, use of secondary heat from biogas needs conversion of biogas to electricity and then to heat resulting in large heat losses. The heat loss is mainly associated with the performance inefficiencies of the engine and the amount of $\mathrm{CO}_{2}$ present [64]. The inefficiency of the engine can be severe if the biogas contains a high concentration of $\mathrm{CO}_{2}$ leading to a low combustion performance of the engine. About two thirds of the energy dissipates to the environment in the processes of electricity generation. Compensation of the wasted heat requires much more resources beyond which the village resources can supply (Fig. 3b). Use of biogas electricity for cooking is not only resourceintensive but also less likely appropriate to address local cooking energy needs due to absence of suitable electricity cooking appliances in rural areas.

Lighting and appliances exclusively need electric energy. In the absence of resource scarcity, use of biogas electricity is more efficient than using biogas lamps 
which consume much gas and deliver insufficient and low quality light $[22,46]$. It has been shown that biogas electricity can be a solution for the village lighting energy demand if sharing for cooking is not involved [66]. This means that the sufficiency and reliability of the available biogas energy resources are realized only when the biogas is either used for cooking or for appliances. This implies the viability of the communal biogas system in solving the rural village energy needs with appropriate digestion and conversion processes.

\section{Consideration of solar energy as alternative and its implication}

An alternative estimate is made with solar energy conversion and use. Use of solar energy for cooking is a mature technology dating back about four centuries although rarely considered as an alternative today [55]. CSCs concentrate direct solar energy to heat using a reflector and a concentrator. The process of concentration requires strong radiation absorbed from clear skies. Moreover, the design of the concentrator determines the amount of energy obtained per area of solar collector. With average concentration efficiency, the amount of energy annually obtained per square meter area (2.4 GJ) can be comparable with about $1.6 \mathrm{t}$ of wood used in traditional stoves. This is a huge saving when the human and environmental costs of collecting wood fuel are taken into account. Once installed, the CSC does not require any fuel, but in contrast, it does take a long time of cooking due to its low thermal efficiencies. However, its low thermal efficiency can be improved through design modifications [56, 58]. For instance, [67] has developed an improved prototype solar cooker with a mirror diameter of $1.2 \mathrm{~m}$ with an efficiency of about $60 \%$ sufficient to cook Injera for about 150 people in Ethiopia. Most of the design modifications have included the suitability to use the system at any time and place and at any scale. Nahar et al. [68] have developed a modified box type community solar cooker with the absorber size of $3.12 \mathrm{~m}^{2}$ sufficient to cook food for about 80 people modifying the width to length ratio of the reflector. Franco et al. developed a multiple use communal solar cooker with three different kinds of absorbers performing different functions with a concentrator area of $2 \mathrm{~m}^{2}$ sufficient to cook food for 30 persons [69]. A design modification with thermal energy storage has been developed and tested with local materials such as used engine oil, vegetable oil, sand, and steam to enable late noon cooking [53].

Alternatively, a communal cooking scheme can be arranged with scheduled daytime cooking. For instance, in Ethiopia, households bake Injera every 2 days where one stove can serve several households. With a prototype developed to cook Injera [67], it is possible to cook Injera sufficient for all people living in the village considered for this study. CSCs are technologically mature, easily adaptable, convenient to use at any time, and cheap technology with high ecological benefits $[52,57,70]$. This implies the potential competitiveness of CSC with that of biogas stoves to meet the cooking energy demand of the village at any time of the day taking into account design modifications. Moreover, the available reliable radiation with high intensity throughout the year in the tropical climates can be a stimulus for better efficiency improvements. In most parts of Ethiopia, the daily solar radiation intensity oscillates between 5 and $7 \mathrm{kWh} / \mathrm{m}^{2}$ [1]. With a minimum amount of radiation, it is possible to obtain about 2 GJ of useful energy per year (equivalent to about $1.3 \mathrm{t}$ of firewood used in traditional stoves).

Solar PV directly converts solar energy into electrical energy using semi-conducting compounds. Its solar-toelectricity conversion efficiency depends on the amount of shortwave radiation absorbed and converted into electric currents [71]. The currently available technologies only convert less than $20 \%$ of the solar radiation to electricity, requiring the need to build large size PV systems to meet the cooking demands. Building large size systems (about $6 \mathrm{~m}^{2} \mathrm{PV} /$ household for the cooking demand) might be economically inconceivable in rural areas. Cost is the main limiting factor in the adoption and use of solar PVs in rural areas [72]. However, it is viable to satisfy the appliance electricity demand, since the appliance demand accounts for only about $10 \%$ of the demands. Therefore, each household requires about $0.7 \mathrm{~m}^{2}$ of PV panel to meet their appliances and lighting demand considered in this study. This means that with the present efficiency and cost, the electricity from solar PV is only a viable option for lighting and low voltage appliances but less likely for solving the cooking energy needs of the village. However, a hybrid of CSC and solar PV can be an alternative to biogas to provide adequate energy services to a rural village where installation of biogas is not feasible. This option is suitable to be applied in arid and semi-arid areas with high intensity solar radiation and a shortage of water for biogas production.

\section{Conclusions}

Households in the village need a combination of heat and electricity for their energy demand. The energy comes from waste streams and solar energy resources. The waste streams are limited by the number of cows, size of land, and number of people present in the village. Only with a maximal resource use, biogas demand for cooking and electricity can be met. Not enough resources are available for a biogas electricity system for cooking and appliances. Most resource combinations are able to supply enough biogas for cooking. In areas where installation of biogas is not possible, CSC can be used as 
an alternative for cooking. A moderate sized area is needed for PV panels for electricity for appliances and for concentrated solar cooking. A very substantial PV collector area would be needed to generate enough electricity for cooking and appliances. Both biogas and CSC technologies are easily adaptable to cook local foods and meet local expectations. Electric energy provides better quality energy for cooking but is economically less likely to be an option in rural areas with the presently available resources and technologies. In general, with appropriate and efficient production and conversion, the available resources of the village are sufficient to meet their energy demands.

\section{Abbreviations}

AD: Anaerobic digester; CSC: Concentrate solar cooker; CSP: Concentrate solar power; PV: Photovoltaic; RPR: Residue to product ratio; SHS: Solar home system

\section{Acknowledgements}

The authors gratefully acknowledge Professor Ton Schoot Uiterkamp and Professor Henri C. Moll, Center for Energy and Environmental Sciences of the University of Groningen, for the valuable comments and suggestions on the study.

\section{Authors' contributions}

GTT (Gudina) designed the study, analyzed the data, and wrote the first draft of the manuscript. SN (Sanderine) participated in the design of the study, supervised the whole process, and reviewed the final manuscript. Both authors read and approved the final manuscript.

\section{Competing interests}

The authors declare that they have no competing interests.

\section{Publisher's Note}

Springer Nature remains neutral with regard to jurisdictional claims in published maps and institutional affiliations.

\section{Author details}

${ }^{1}$ Department of Environmental Health Sciences and Technology, Jimma University, Jimma, Ethiopia. ${ }^{2}$ Center for Energy and Environmental Sciences, Nijenborgh 4, 9747 AG Groningen, Netherlands.

Received: 26 May 2017 Accepted: 27 September 2017

Published online: 01 November 2017

\section{References}

1. Tucho GT, Weesie PD, Nonhebel S (2014) Assessment of renewable energy resources potential for large scale and standalone applications in Ethiopia. Renew Sust Energ Rev 40:422-431

2. UNDP, W et al (2009) The energy access situation in developing countries. A review focussing on least developed countries and Sub-Saharan Africa. United Nations Development Programme and World Health Organization, UNDP, New York

3. Bond T, Templeton MR (2011) History and future of domestic biogas plants in the developing world. Energy Sustain Dev 15(4):347-354

4. Mengistu $\mathrm{M}$ et al (2015) A review on biogas technology and its contributions to sustainable rural livelihood in Ethiopia. Renew Sust Energ Rev 48:306-316

5. Nzila C et al (2012) Multi criteria sustainability assessment of biogas production in Kenya. Appl Energy 93:496-506

6. Parawira W (2009) Biogas technology in sub-Saharan Africa: status, prospects and constraints. Rev Environ Sci Biotechnol 8(2):187-200

7. Orskov ER et al (2014) Overview of holistic application of biogas for small scale farmers in Sub-Saharan Africa. Biomass Bioenergy 70:4-16

8. Parida B, Iniyan S, Goic R (2011) A review of solar photovoltaic technologies. Renew Sust Energ Rev 15(3):1625-1636

9. Surendra KC et al (2014) Biogas as a sustainable energy source for developing countries: opportunities and challenges. Renew Sust Energ Rev 31(0):846-859
10. Rupf GV et al (2016) Broadening the potential of biogas in Sub-Saharan Africa: an assessment of feasible technologies and feedstocks. Renew Sust Energ Rev 61:556-571

11. Tucho GT, Nonhebel S (2015) Bio-wastes as an alternative household cooking energy source in Ethiopia. Energies 8:9565-9583

12. Mwirigi JW, Makenzi PM, Ochola WO (2009) Socio-economic constraints to adoption and sustainability of biogas technology by farmers in Nakuru Districts, Kenya. Energy Sustain Dev 13(2):106-115

13. Roubík H et al (2016) Addressing problems at small-scale biogas plants: a case study from central Vietnam. J Clean Prod 112:2784-2792

14. Bedi AS, Pellegrini L, Tasciotti L (2015) The effects of Rwanda's biogas program on energy expenditure and fuel use. World Dev 67:461-474

15. Jewitt S (2011) Geographies of shit: spatial and temporal variations in attitudes towards human waste. Prog Hum Geogr 35(5):608-626

16. Jewitt S (2011) Poo gurus? Researching the threats and opportunities presented by human waste. Appl Geogr 31(2):761-769

17. Rulkens W (2007) Sewage sludge as a biomass resource for the production of energy: overview and assessment of the various optionst. Energy Fuel 22(1):9-15

18. Sosnowski P, Wieczorek A, Ledakowicz S (2003) Anaerobic co-digestion of sewage sludge and organic fraction of municipal solid wastes. Adv Environ Res 7(3):609-616

19. Kanase-Patil AB, Saini RP, Sharma MP (2010) Integrated renewable energy systems for off grid rural electrification of remote area. Renew Energy 35(6): 1342-1349

20. Mainali B et al (2014) Assessing rural energy sustainability in developing countries. Energy Sustain Dev 19(0):15-28

21. Rahman MM et al (2014) Hybrid application of biogas and solar resources to fulfill household energy needs: a potentially viable option in rural areas of developing countries. Renew Energy 68(0):35-45

22. Tumwesige V, Fulford D, Davidson GC (2014) Biogas appliances in sub-Sahara Africa. Biomass Bioenergy 70:40-50

23. Cuce E, Cuce PM (2013) A comprehensive review on solar cookers. Appl Energy 102:1399-1421

24. Kong XQ, Wang RZ, Huang XH (2004) Energy efficiency and economic feasibility of CCHP driven by stirling engine. Energy Convers Manag 45(9-10): 1433-1442

25. CSA. Land utilizations, crop production and livestock survey report. National statistical survey 2012 [cited 2014 May]; Available from: http://www.csa.gov.et/.

26. Nzila C et al (2010) Biowaste energy potential in Kenya. Renew Energy 35(12):2698-2704

27. Rosillo-Calle F. (2007) The biomass assessment handbook: bioenergy for a sustainable environment. Earthscan https://books.google.com.et/books/ about/The_Biomass_Assessment_Handbook.html?id=Jmuz3rysSpAC\&redir_ esc $=y$.

28. Akinbami J-F et al (2001) Biogas energy use in Nigeria: current status, future prospects and policy implications. Renew Sust Energ Rev 5(1):97-112

29. Batzias FA, Sidiras DK, Spyrou EK (2005) Evaluating livestock manures for biogas production: a GIS based method. Renew Energy 30(8):1161-1176

30. Valbuena D et al (2012) Conservation Agriculture in mixed crop-livestock systems: scoping crop residue trade-offs in Sub-Saharan Africa and South Asia. Field Crop Res 132(0):175-184

31. Heinonen-Tanski H, van Wijk-Sijbesma C (2005) Human excreta for plant production. Bioresour Technol 96(4):403-411

32. Langergraber $G$, Muellegger $E$ (2005) Ecological sanitation - a way to solve global sanitation problems? Environ Int 31(3):433-444

33. Rose C, Parker A, Jefferson B, Cartmell E (2015). The Characterization of Feces and Urine: A Review of the Literature to Inform Advanced Treatment Technology. Critical Reviews in Environmental Science and Technology, 45(17):1827-1879. doi:10.1080/10643389.2014.1000761.

34. Niwagaba C (2009) Treatment technologies for human faeces and urine, vol 2009

35. Jönsson $\mathrm{H}$ et al (2004) Guidelines on the use of urine and faeces in crop production. EcoSanRes Programme. www.ecosanres.org/pdf_files/ESRfactsheet-06.pdf.

36. NASA. Surface meteorology and solar energy 2015 [cited 201511 March]; Available from: https://eosweb.larc.nasa.gov/sse/.

37. Amigun B, von Blottnitz H (2010) Capacity-cost and location-cost analyses for biogas plants in Africa. Resour Conserv Recycl 55(1):63-73

38. Tadesse $L$ (2010) Study on current status of institutional biogas plants in Ethiopia. Addis Ababa University. www.etd.aau.edu.et/bitstream/123456789/ 1011/3/TadesseLulie.pdf. 
39. Leta B (2009) National survey on current stats of institutional biogas systems installed in Ethiopia. gtz, Addis Ababa

40. Yue $Z$ et al (2013) Effects of dairy manure and corn stover co-digestion on anaerobic microbes and corresponding digestion performance. Bioresour Technol 128:65-71

41. Wang $X$ et al (2012) Optimizing feeding composition and carbon-nitrogen ratios for improved methane yield during anaerobic co-digestion of dairy, chicken manure and wheat straw. Bioresour Technol 120:78-83

42. Li X et al (2009) Anaerobic co-digestion of cattle manure with corn stover pretreated by sodium hydroxide for efficient biogas production. Energy Fuel 23(9):4635-4639

43. Kirchmann H, Pettersson S (1994) Human urine-chemical composition and fertilizer use efficiency. Fertil Res 40(2):149-154

44. Comino E, Rosso M, Riggio V (2010) Investigation of increasing organic loading rate in the co-digestion of energy crops and cow manure mix. Bioresour Technol 101(9):3013-3019

45. Zinoviev $S$ et al (2010) Next-generation biofuels: survey of emerging technologies and sustainability issues. ChemSusChem 3(10):1106-1133

46. Rajendran K, Aslanzadeh S, Taherzadeh MJ (2012) Household biogas digesters - a review. Energies 5(8):2911-2942

47. Bhattacharya S, Salam PA (2002) Low greenhouse gas biomass options for cooking in the developing countries. Biomass Bioenergy 22(4):305-317

48. Bari S (1996) Effect of carbon dioxide on the performance of biogas/diesel duel-fuel engine. Renew Energy 9(1-4):1007-1010

49. Hur KB, Rhim SK, Park JK (2009) Mechanical characteristics evaluation of biogas micro turbine power systems. J Loss Prev Process Ind 22(6):1003-1009

50. Pöschl M, Ward S, Owende P (2010) Evaluation of energy efficiency of various biogas production and utilization pathways. Appl Energy 87(11): 3305-3321

51. Green MA et al (2015) Solar cell efficiency tables (Version 45). Prog Photovolt Res Appl 23(1):1-9

52. Regattieri A et al (2016) Innovative portable solar cooker using the packaging waste of humanitarian supplies. Renew Sust Energ Rev 57:319-326

53. Muthusivagami $R$, Velraj $R$, Sethumadhavan $R$ (2010) Solar cookers with and without thermal storage — a review. Renew Sust Energ Rev 14(2):691-701

54. Ahmad B (2001) Users and disusers of box solar cookers in urban India-: implications for solar cooking projects. Sol Energy 69:209-215

55. Saxena A, Pandey S, Srivastav G (2011) A thermodynamic review on solar box type cookers. Renew Sust Energ Rev 15(6):3301-3318

56. Widyolar BK et al (2017) Design, simulation and experimental characterization of a novel parabolic trough hybrid solar photovoltaic/ thermal (PV/T) collector. Renew Energy 101:1379-1389

57. Lecuona A et al (2013) Solar cooker of the portable parabolic type incorporating heat storage based on PCM. Appl Energy 111:1136-1146

58. Ghosh S, Biswas P, Neogi S (2017) Thermal performance of solar cooker with special cover glass of low-e antimony doped indium oxide (IAO) coating. Appl Therm Eng 113:103-111

59. Pohekar S, Ramachandran M (2006) Utility assessment of parabolic solar cooker as a domestic cooking device in India. Renew Energy 31 (11):1827-1838

60. Bekele G, Tadesse G (2012) Feasibility study of small Hydro/PV/Wind hybrid system for off-grid rural electrification in Ethiopia. Appl Energy 97(0):5-15

61. Tucho GT et al (2016) Problems with biogas implementation in developing countries from the perspective of labor requirements. Energies 9(9):750

62. Burke PJ, Dundas G (2015) Female labor force participation and household dependence on biomass energy: evidence from national longitudinal data. World Dev 67:424-437

63. Avery LM et al (2014) Potential for pathogen reduction in anaerobic digestion and biogas generation in Sub-Saharan Africa. Biomass Bioenergy 70:112-124

64. Sahoo B, Sahoo N, Saha U (2009) Effect of engine parameters and type of gaseous fuel on the performance of dual-fuel gas diesel engines-a critical review. Renew Sust Energ Rev 13(6):1151-1184

65. Eshete G, Sonder K, ter Heegde F (2006) Report on the feasibility study of a national programme for domestic biogas in Ethiopia. SNV, Addis Ababa

66. Reddy AK (2004) Lessons from the Pura community biogas project. Energy Sustain Dev 8(3):68-73

67. Gallagher A (2011) A solar fryer. Sol Energy 85(3):496-505
68. Nahar N, Gupta J, Sharma P (1993) Performance and testing of an improved community size solar cooker. Energy Convers Manag 34(4):327-333

69. Franco J, Cadena C, Saravia L (2004) Multiple use communal solar cookers. Sol Energy 77(2):217-223

70. Nandwani SS (1996) Solar cookers — cheap technology with high ecological benefits. Ecol Econ 17(2):73-81

71. Crabtree GW, Lewis NS (2007) Solar energy conversion. Phys Today 60(3): 37-42

72. Baurzhan S, Jenkins GP (2016) Off-grid solar PV: is it an affordable or appropriate solution for rural electrification in Sub-Saharan African countries? Renew Sust Energ Rev 60:1405-1418

\section{Submit your manuscript to a SpringerOpen ${ }^{\circ}$ journal and benefit from:}

- Convenient online submission

- Rigorous peer review

- Open access: articles freely available online

- High visibility within the field

- Retaining the copyright to your article

Submit your next manuscript at springeropen.com 